\title{
MORFOLOGIA DA GLĀNDULA INTERMAXILAR \\ DO SAPO (Bufo paracnemis Lutz, 1925)
}

\author{
Marlene Soares Dias Alves ${ }^{1}$
}

\begin{abstract}
The intermaxillary gland of Bufo paracnemis Lutz, 1925 is located at the pre-nasal area being divided anteriorly by the ascendent processes of the intermaxillary bone. The secretory tubules converge to form very ramified ducts which drain into a common opening in a fosseta underlying the vomer bone.

The cells of the intermaxillary gland were be classified in four distinct types: Light-granule secretory; Dark-granule secretory; ciliated and basal cells. The light-granule secretory cells, are the main type of the secretory tubules, which are also found, in smaller numbers, in the excretory ducts. The darkgranule secretory cells appear in a low number, both in the secretory tubules and in the excretory ducts. Degranulated cells are frequently found in the excretory ducts and represent the degranulated phase of dark-granule secretory cells. The ciliated cells occur only in the excretory ducts. The basal cells occur in small number in the excretory ducts and secretory tubules. In the excretory ducts these cells are regarded as being mioepithelial cells.

Although usually described in the literature as mucous, the secretory cells of the intermaxillary gland have serous characteristics.

The intermaxillary gland is the first salivary gland to appear in the vertebrate evolution. Its duct system is uniformly lined by ciliated cells and scattered secretory cells. This indicates that in the evolution, of salivary glands, there was a diversification of the duct system, together with progressive concentration of secretory cells in special areas of this system.
\end{abstract}

\section{INTRODUÇÃO}

Estudos comparativos e filogenéticos sobre as glândulas salivares de vertebrados são de interesse, principalmente, pelo fato destas estruturas apresentarem grande diversidade morfológica (Fahrenholtz, 1937; Andrew, 1964; Junqueira \& Fava de Moraes, 1965).

Dentro desta abordagem, o estudo das glândulas salivares de anfíbios é de fundamental importância, pois excetuando-se a glândula bucal de larvas de ciclóstomos, estas glândulas faltam nos vertebrados de hábitos aquáticos. Na evolução dos vertebrados, surgem pela primeira vez nos anfíbios (Reichel, 1883; Fahrenholtz, 1937; Junqueira, 1967) e seu estudo permite a caracterização de

1 Departamento de Morfologia, Instituto de Ciências Biológicas, Universidade Federal de Minas Gerais, Belo Horizonte - 30.000 . 
um padrão primitivo de organização glandular, a partir do qual, teriam evoluído as glândulas salivares dos demais vertebrados.

A glândula intermaxilar foi assim denominada por suas relações com o osso do mesmo nome, sendo descrita inicialmente na salamandra por Schelegel (1833), mas ocorrendo na quase totalidade de anuros e urodelos (Wiedersheim, 1876; Oppel, 1900; Fahrenholtz, 1934; De Vos, 1935).

O sapo Bufo paracnemis, por ser um dos maiores anuros neotropicais conhecidos, constitui-se um adequado modelo para estudo da anatomia e da histologia da glândula intermaxilar.

\section{MATERIAL E MÉTODOS}

Foram utilizados 30 sapos da espécie Bufo paracnemis Lutz, 1925, na maoria do sexo masculino, coletados em Belo Horizonte, Minas Gerais, Brasil. 0 comprimento crânio-caudal dos animais variou de 9 a $18 \mathrm{~cm}$ e o peso corporal de 45 a 500 gramas.

Sob anestesia, removia-se a cabeça do animal. Em seguida, seccionavam-se as comissuras bucais estendendo-se o corte pela região dorsal, anterior às órbitas, com o cuidado de se manter o palato íntegro, incluindo-se as coanas. A fixação e descalcificação do material foram feitas conforme Richman et alii (1947), seguindo-se desidratação em álcoois, diafanização em xilol e inclusão em parafina.

Utilizando-se outro procedimento, a glândula era dissecada e os fragmentos fixados em líquido de Helly por 4 horas, com posterior inclusão em parafina, ou em glutaraldeído $3 \%$, em tampão fosfato $0,1 \mathrm{M}$, seguido da pós-fixação em tetróxido de ósmio 2\% no mesmo tampão e inclusão em Epon-812. Os cortes eram corados com tricrômico de Gomori ou azul de toluidina a $1 \%$.

Para estudos anatômicos, os animais eram perfundidos com solução de Ringer $30 \%$ a $40 \mathrm{C}$, seguida de solução de formol $10 \%$, preparadas de acordo com Williams (1948). Retirava-se então a cabeça do animal, colocando-a em formol a $10 \%$ por 8 dias. Após este tempo, retirava-se o corpo glandular incluindo-se a mucosa bucal, até a região posterior às coanas. A peça assim obtida, era submetida aos procedimentos propostos por Williams \& Boyer (1965) para diferenciar derivados epiteliais em blocos espessos. Assim, os túbulos secretores e ductos excretores da glândula intermaxilar puderam ser visualizados sob microscópio estereoscópico.

Para a análise quantitativa da freqüência dos tipos celulares existentes na glândula intermaxilar, contaram-se todas as células dos ductos excretores em cortes espessos corados com azul de toluidina ou algumas células dos túbulos secretores coincidentes com os pontos da ocular integradora KPL-8x - Zeiss.

\section{RESULTADOS}

A glândula intermaxilar do sapo Bufo paracnemis Lutz, 1925 apresenta um corpo glandular e ductos excretores.

A maior parte do corpo glandular encontra-se na área pré-nasal, sendo recoberta dersalmente pelo tegumento da cabeça, ao passo que sua porção voltada para a cavidade bucal é revestida pela mucosa oral. A cápsula nasal cartilaginosa 
limita caudalmente o corpo glandular, enquanto na região oral, o limite dorsolateral é estabelecido pelo vômer. Na área pré-nasal, o corpo glandular é parcialmente dividido pelos processos ascendentes do osso intermaxilar em três porções, uma intermédia e duas laterais (Fig. 1). O corpo glandular estende-se ainda em outras direções: lateralmente, ao longo da borda inferior do osso maxilar; caudalmente, abaixo da cápsula nasal cartilaginosa e do vômer e em menor extensão, quando penetra na fenestra naso-basal, aproximando-se da glândula nasal medial (Fig. 8).

Os ductos excretores originam-se dos túbulos secretores do corpo glandular e, durante seus trajetos pela mucosa oral, recebem produtos dos túbulos secretores que os acompanham. Estes ductos variam de quatro a oito de cada lado da mucosa oral. Os ductos mediais são os mais numerosos. Os ductos intermediários apresentam trajeto curto e geralmente reúnem-se aos ductos laterais, desembocando anteriormente aos mediais. Os ductos excretores são muito ramificados, principalmente na região mais próxima ao corpo glandular, onde continuam-se com os túbulos secretores e então, não podem mais ser diferenciados (Fig. 2).

O óstio de abertura glandular é o local comum de desembocadura dos ductos excretores e de alguns túbulos secretores. É formado por invaginação do epitélio oral, com forma aproximada de meia-lua e se abre em uma fosseta do vômer, recoberta pela mucosa oral, na região anterior e medial às coanas (Fig. 2). $\mathrm{O}$ epitélio oral é estratificado prismático ciliado com células caliciformes, mas à medida que se invagina no óstio de abertura, torna-se simples, com poucas células ciliadas, surgindo ainda outros tipos de células secretoras, não caliciformes (Fig. 11).

Alguns túbulos secretores e ductos excretores mediais da glândula intermaxilar, localizam-se muito próximos a túbulos secretores das glândulas faríngeas, situados medialmente às coanas, na região da fosseta do vômer. Entretanto, as glândulas faríngeas possuem aspecto histológico distinto da glândula intermaxilar e seus túbulos glandulares desembocam diretamete na superfície da coana (Figs. 2 e 7).

De acordo com o aspecto e disposição dos túbulos secretores e ductos excretores, a glândula intermaxilar é uma glândula exócrina, composta e tubulosa. Os túbulos secretores têm um aspecto seroso, possuindo células com granulação acidofila e núcleo basal (Figs. 3, 4, 5 e 6). Seus lumes são geralmente amplos, podendo variar de acordo com a altura de suas células e contém material acidofilo no seu interior (Fig. 4).

A caracterização dos tipos celulares da glândula foi feita utilizando-se cortes corados em tricrômico de Gomori, bem como cortes espessos em Epon-8-12, corados com azul de toluidina. O critério para denominação de cada célula foi baseado em aspectos ultra-estruturais (Alves, 1979).

Dados contidos na Tabela 1 demonstram que as células secretoras de grânulos claros (CSGC) ocorrem principalmente nos túbulos secretores, onde constituem o tipo celular mais freqüente (Fig. 10). Elas possuem forma prismática, medindo cerca de $20 \mu \mathrm{m}$ de comprimento e até $10 \mu \mathrm{m}$ de largura. Seu núcleo é basal, esferoidal e de contorno irregular, com diâmetro médio de 4,5 $\mu \mathrm{m}$. A cromatina é mais condensada na sua periferia, enquanto o nucléolo ocupa a região central. O citoplasma supra-nuclear apresenta-se repleto de granulações acidofi- 
Revta bras. Zool. las, mas a região perinuclear, bem como as laterais da célula, são basófilas, devido a presença de abundante ergastoplasma. Em cortes espessos, a granulação destas células não se cora com azul de toluidina e apenas as áreas contendo ergastoplasma aparecem basófilas (Figs. 5 e 6).

As células secretoras de grânulos escuros (CSGE) ocorrem com freqüência tanto nos túbulos como nos ductos excretores (Tabela 1). Elas podem estar agrupadas ou esparsadas entre os outros tipos celulares nos túbulos e ductos da glândula intermaxilar (Figs. 6, 10 e 12). Possuem forma prismática baixa, com $5,5 \mu \mathrm{m}$ de largura e $10 \mu \mathrm{m}$ de altura. Seu núcleo é esférico de contorno regular, com diâmetro de $3,5 \mu \mathrm{m}$, cromatina agrupada na periferia e um nucleólo excêntrico. O que mais caracteriza estas células é a presença de granulações basófilas que se distribuem na região supra-nuclear. A quantidade destes grânulos pode variar de tal modo que, algumas células apresentam-se aparentemente sem material de secreção (desgranuladas).

As células secretoras desgranuladas (CSD) tem características histológicas idênticas às $\mathrm{CSGE}$, com exceção da sua granulação que não é visível à microscopia óptica e seu tamanho médio com cerca de $7 \mu \mathrm{m}$ de altura e $5 \mu \mathrm{m}$ de largura. Entretanto, estudos ao M.E.T. mostraram a existência de grânulos densos esparsos no citoplasma destas células (Fig. 12).

O único tipo celular encontrado apenas nos ductos excretores da glândula intermaxilar é a célula ciliada (CC). (Tabela 1). São células geralmente cuboidais ou afuniladas, estreitando-se na porção basal. Possuem em média 6,5 $\mu \mathrm{m}$ de altura e $6 \mu \mathrm{m}$ de largura, mas podem apresentar até $2 u \mathrm{~m}$ nos pontos de estreitamento. Seu núcleo é central e irregular, apresentando identações e diâmetro aproximado de $3,8 \mu \mathrm{m}$. A cromatina é mais condensada e homogênea que nas células secretoras, o que torna o nucleólo pouco evidente.

As células basais (CB) são muito mais freqüentes nos ductos excretores que nos túbulos secretores (Tabela 1), situando-se entre a lâmina basal e as células epiteliais ciliadas e secretoras. A maioria destas células têm características de células mioepiteliais, já bem conhecidas nas glândulas salivares de mamíferos. Elas possuem núcleo alongado com diâmetro aproximado de 7,5 $\mu \mathrm{m}$ contendo cromatina condensada na sua periferia e nucleólo evidente. 0 comprimento das células basais é dependente de seus prolongamentos e sua largura média é de $3,5 \mu \mathrm{m}$.

\section{DISCUSSÃO}

$\mathrm{Na}$ área pré-nasal, os ramos ascendentes do osso intermaxilar dividem parcialmente o corpo da glândula intermaxilar do Bufo paracnemis em três porções. Esta divisão, porém, não é nítida na porção caudal da glândula. Este fato está de

FIGS. $1-2$ - Bufo paracnemis. 1, Cabeça em vista frontal, mostrando o corpo da glândula intermaxilar dividido pelos processos ascendentes do osso intermaxilar (OI), em três porções: uma intermédia (seta grande) e duas laterais (setas pequenas). 2, Metade direita da região do palato mostrando a parte caudal do corpo da glândula intermaxilar (CGI), recoberta pela mucosa oral. As barras indicam ductos excretores laterais (DEL), intermediários (DEI) e mediais (DEM), bem como, alguns túbulos secretores (TS). Todos estes ductos e túbulos desembocam no óstio glandular (não representado), localizado em uma fosseta (FO) vomeriana (VO). Ao lado da coana (CO) estão as massas laterais e mediais da glândula faríngea (GF). 
Vol. 5(4), 1988

acordo com as descrições de Wiedersheim (1876), Oppel (1900), Oeder (1905, 1906), Müller (1932), e Fahrenholtz (1937) para várias espécies de anfíbios e coincide também com observações de Ramaswani (1936) que cita a não existên-
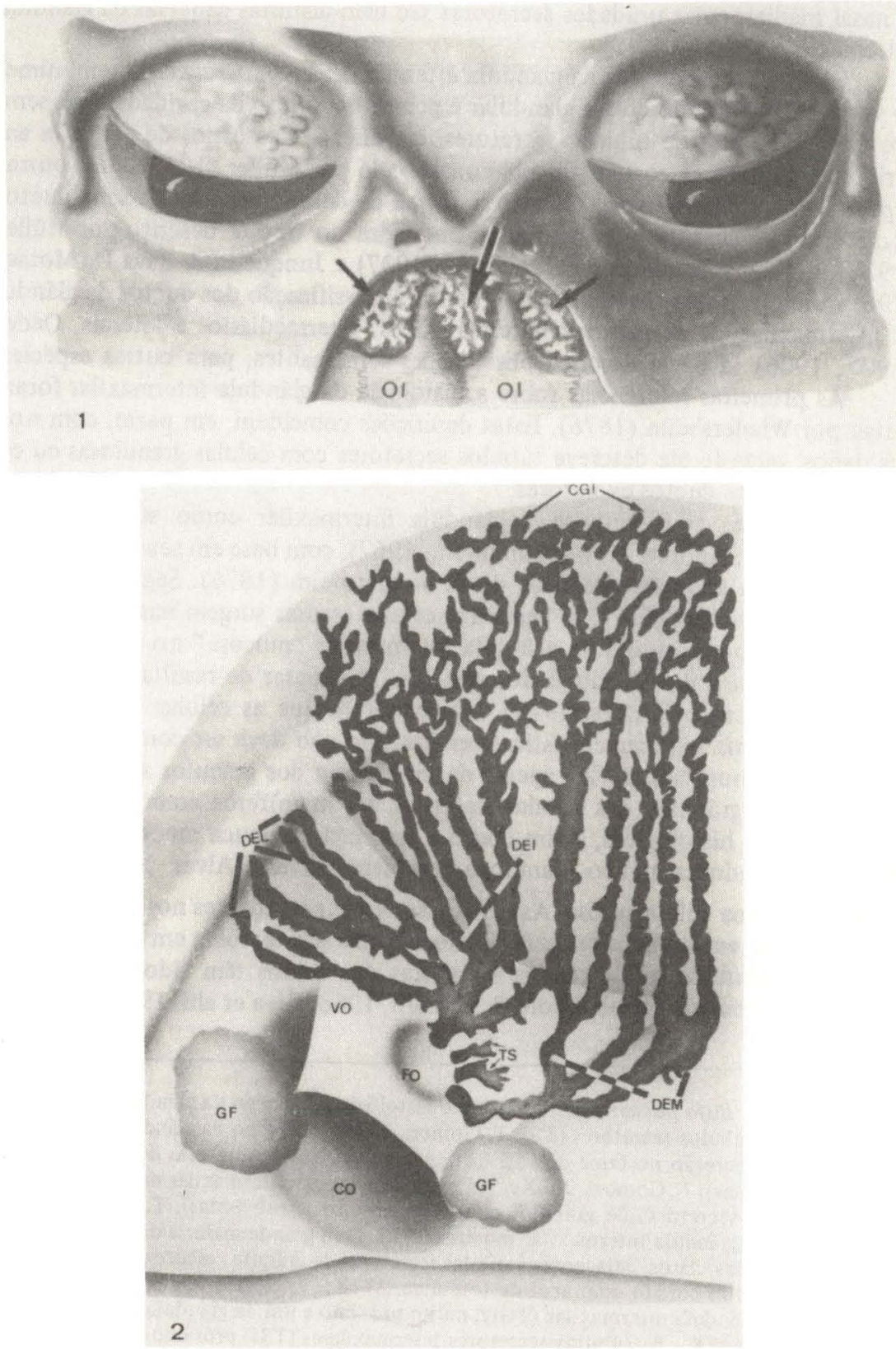
cia de divisão nítida da glândula intermaxilar no gênero Bufo. Confirmando os achados de Müller (1932) para outras espécies de Bufo, verificamos que a glândula intermaxilar do Bufo paracnemis, além de ocupar a área pré-nasal, estende-se em outras direções e penetra pela fenestra naso-basal, aproximando-se da glândula nasal medial, cujas unidades secretoras são bem distintas daquelas da glândula intermaxilar.

Os ductos excretores da glândula intermaxilar ue $B$. paracnemis, em número variável, partem do corpo glandular e percorrem o teto da cavidade oral, sempre acompanhados de túbulos secretores, em direção aos óstios de abertura anteriores e mediais às coanas, fato já considera to por Müller (1932), para outras espécies do wišsmo gênero. Quanto à forma de desembocadura de seus ductos excretores, a glândula in 'ermaxilar se enquadra no tipo V descrito por Müller (1932), e é considerada por Fahrenholtz (1937) e Junqueira \& Fava De Moraes (1965) uma glândula diastomática. Quanto à classificação dos ductos da glândula intermaxilar de $B$. paracnemis em mediais, intermediários e laterais, Oeder (1905, 1906) já havia descrito observações semelhantes, para outras espécies.

As primeiras referências sobre a histologia da glândula intermaxilar foram feitas por Wiedersheim (1876). Estas descrições coincidem, em parte, com nossos dados, quando ele descreve túbulos secretores com células granulosas ou células ciliadas nos ductos excretores.

Até hoje, considerou-se a glândula intermaxilar como sendo mucosa (Tu=ter, 1958; Andrew, 1964; Junqueira, 1967), com base em seu aspecto morfologico e sua secreção descritos desde Wiedersheim (1876). Segundo Tucker (1958) e Junqueira (1967), as primeiras células serosas surgem nas glândulas de veneno dos répteis, estando a glândula intermaxilar "mucosa" no início da evolução filogenética das glândulas dos vertebrados. Apesar de resultados histológicos e histoquímicos (Alves, 1979) demonstrarem que as células secretoras do Bufo paracnemis têm características serosas, isto não deve ser considerado para todos os anfíbios. Nas CSGC, apesar da morfologia dos grânulos ser mais semelhante à dos grânulos das células descritas em mamíferos como mucosas, as características histológicas, assim como a presença de pouca mucossubstância e de retículo endoplasmático granuloso bem desenvolvido (Alves, 1979) indicam tratar-se de uma célula serosa. As CSGC são também evidentes nos ductos excretores, embora em número reduzido, fato considerado também em glândulas salivares de mamíferos, onde células secretoras dos ácinos têm sido descritas nos ductos intralobulares (Shackleford \& Wilborn, 1968; Riva et alii, 1976).

FIGS. $3-8$ - Bufo paracnemis. 3, Aspecto histológico do corpo da glândula intermaxilar mostrando túbulos secretores (TS). T. Gomori. 154X. 4, Corpo da glândula intermaxilar mostrando secreção no lume dos TS (seta grande) e células secretoras de grânulos claros (setas pequenas). T. Gomori. 208X. 5, Corpo da glândula intermaxilar mostrando um TS com células secretoras de grânulos claros, de aspecto seroso (setas). T. Gomori. 550X. 6 , Corpo da glândula intermaxilar mostrando TS, com grande maioria de células secretoras de grânulos claros, adjacentes à células secretoras de grânulos escuros (seta). Corte espesso em Epon corado com azul de toluidina. 371X. 7, Região vomeriana, mostrando um TS da glândula intermaxilar (TGI), muito próximo a um da glândula faríngea (TGF). T. Gomori. 448X. 8, Túbulos secretores intermaxilares (TSI) próximos a glândula nasal medial (GNM). T. Gomori. 189X. 
Vol. 5(4), 1988

Os resultados de contagens celulares (Tabela 1) mostram que as CSGE ocorrem com mesma freqüência nos túbulos e ductos da glândula intermaxilar. Já as CSD são mais numerosas nos ductos excretores. Estudos ao M.E.T. mostraram que as CSD são na realidade CSGE com número reduzido de grânulos (Alves, 1979). Esta consideração parece lógica, visto que não foram observadas mitoses que poderiam levar a indicação que fossem fases imaturas das CSGE. O fato

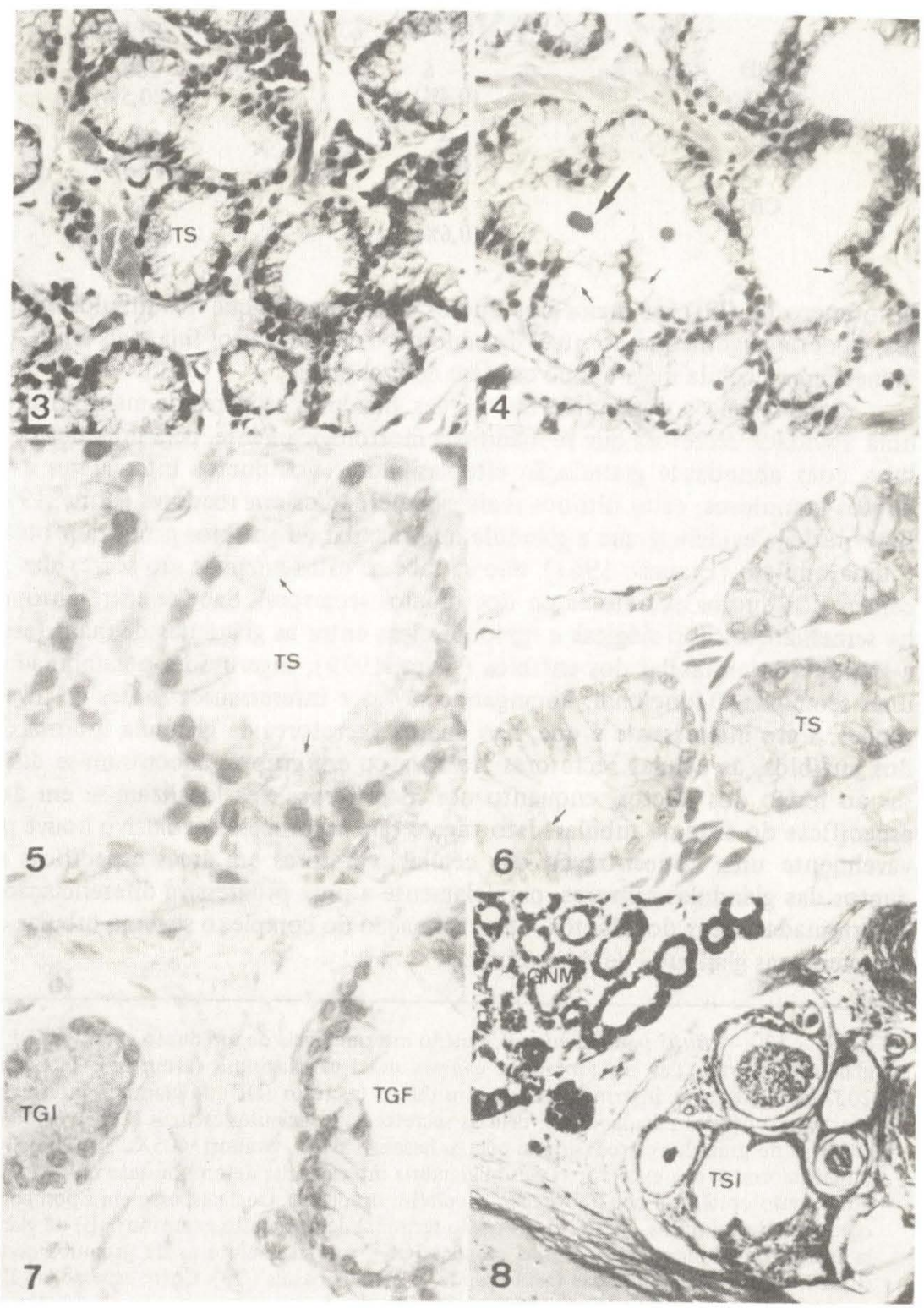


Revta bras. Zool.

TAB. 1 - Freqüência dos tipos celulares nos túbulos secretores e nos ductos excretores da glândula intermaxilar do sapo (Bufo paracnemis Lutz, 1925).

$\begin{array}{ccc}\text { Tipos celulares } & \text { Túbulos secretores } & \text { Ductos excret } \\ \text { CSGC } & 1440 & 6 \\ & (85,3 \%) & (0,8 \%) \\ \text { CSGE } & 232 & 72 \\ & (13,8 \%) & (10,7 \%) \\ \text { CSD } & 6 & 138 \\ & (0,4 \%) & (20,5 \%) \\ \text { CC } & - & 385 \\ & (0 \%) & (57,4 \%) \\ \text { CB } & 11 & 69 \\ & (0,6 \%) & (20,3 \%)\end{array}$

do número de CSD ser maior nos ductos excretores do que nos túbulos secretores, poderia sugerir que ao nível dos ductos, o ciclo secretor seja mais lento, permanecendo a célula mais tempo em fase desgranulada.

Sabe-se que o sistema de ductos das glândulas salivares de mamíferos tem uma atividade secretora que se manifesta morfologicamente, pela presença de células com abundante granulação citoplasmática, nos ductos intercalares e nos ductos granulosos, estes últimos mais característicos em roedores (Lima, 1976). Embora haja evidência que a glândula intermaxilar de anfíbios produza proteases e uma amilase (Francis, 1961), não se sabe se estas enzimas são secretadas por células dos ductos excretores ou dos túbulos secretores. Sabe-se entretanto, que há semelhanças morfológicas e histoquímicas entre as glândulas de mamíferos e a glândula intermaxilar dos anfíbios (Alves, 1979), sugerindo a possibilidade de uma semelhança funcional, abrangendo novas e interessantes fontes de investigações. Fato interessante é que, nos ductos excretores da glândula intermaxilar dos anfíbios, as células secretoras isoladas ou em grupos, encontram-se dispersas ao longo dos ductos, enquanto nos mamíferos, elas localizam-se em áreas específicas do sistema tubular. Isto sugere que no processo evolutivo houve provavelmente uma concentração das células secretoras em áreas específicas dos ductos das glândulas salivares, paralelamente a uma progressiva diferenciação de determinadas áreas dos ductos, até a formação do complexo sistema tubular que caracteriza as glândulas de mamíferos.

FIGS. 9 - 12 - Bufo paracnemis. 9, Porção intermediária de um ducto excretor (DE) da glândula intermaxilar situado sob a capsula nasal cartilaginosa (asterisco). T. Gomori. 203X. 10, Porção intermediária de um ducto excretor (DE) da glândula intermaxilar mostrando células ciliadas (CC); células secretoras de grânulos escuros (CGE); células secretoras de grânulos claros (seta) e células basais (CB). T. Gomori. 405X. 11, Porção terminal de um ducto excretor (DE) da glândula intermaxilar desembocando no óstio glandular, cujo epitélio é contínuo com o epitélio oral (EO). Corte espesso em Epon corado com azul de toluidina. 392X. 12, Porção terminal de um ducto excretor (DE) da glândula intermaxilar mostrando células ciliadas (CC); células secretoras de grânulos escuros (CGE); células desgranuladas (seta grande) e células basais (CB). Corte espesso em Epon corado com azul de Toluidina. $415 \mathrm{X}$. 
Vol. 5(4), 1988

Fato já constatado por Wiedersheim (1876), Oppel (1900) e Müller (1932) é a presença de células ciliadas apenas nos ductos excretores da glândula intermaxilar. Elas têm a mesma forma das CC de revestimento da língua de anfíbios (Zylberberg, 1976, 1977) e possivelmente são tipos celulares constantes nos tubos epiteliais de anfíbios, já que também são encontradas em quase todo canal
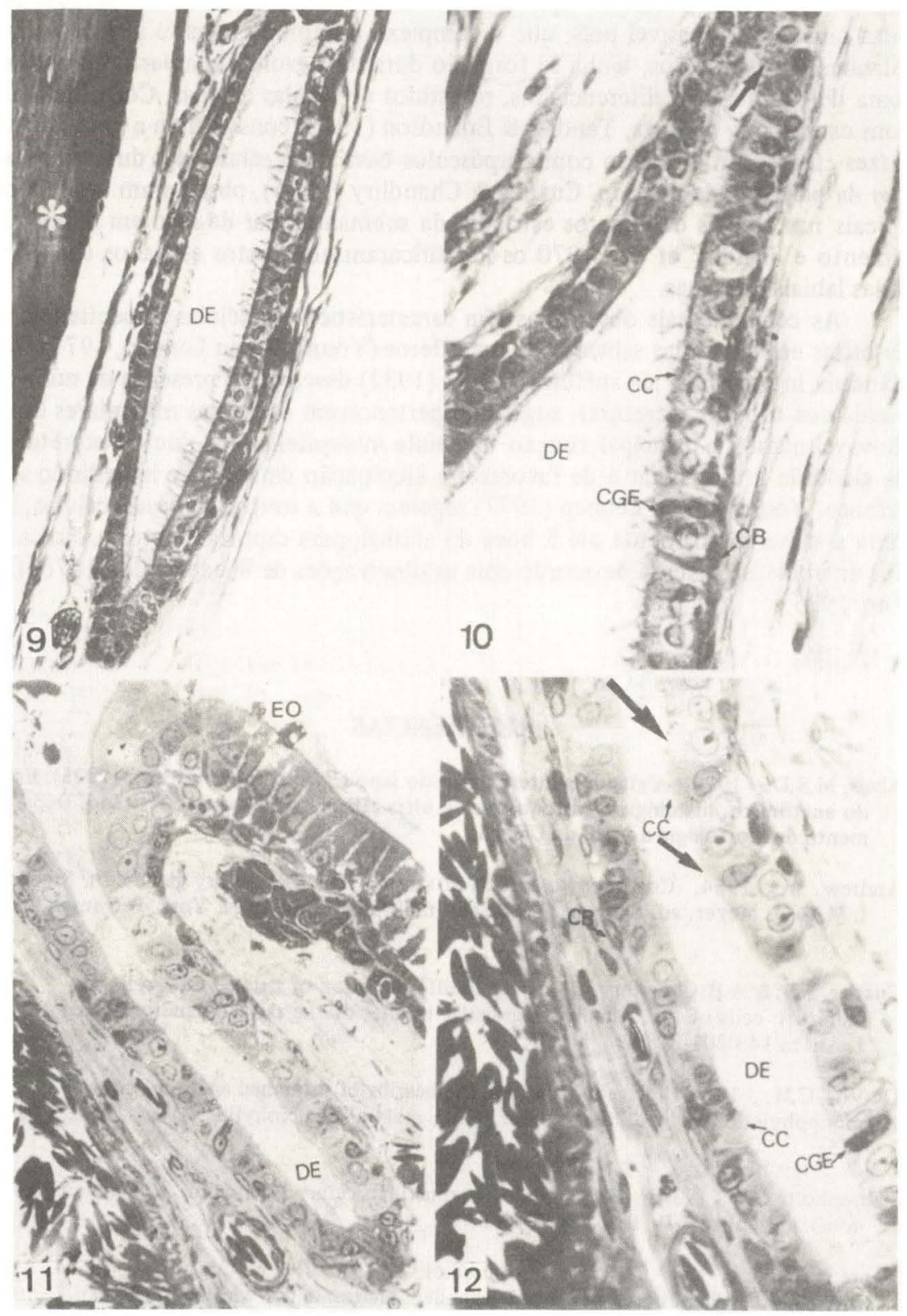
alimentar das larvas de Xenopus laevis (Fox et alii, 1970).

Uma das principais diferenças entre a glândula intermaxilar e as glândulas salivares de mamíferos é a presença, nestas últimas de um complexo sistema de ductos bem diferenciados (Leeson, 1967). Na glândula intermaxilar do sapo, podemos encontrar apenas um tipo de ducto facilmente evidenciado pelas suas células ciliadas. É possível pois, que o complexo sistema observado nas glândulas salivares de mamíferos, tenha se formado durante a evolução, a partir de um sistema de túbulos não diferenciados, revestidos de células ciliadas. Corroborando com este ponto de vista, Tandler \& Erlandson (1976) constataram a presença de raízes ciliares em contacto com corpúsculos basais, em células dos ductos estriados da parótida de macaco. Cuttler \& Chaudhry (1975), observaram centríolos apicais nas células dos ductos estriados da submandibular de rato em desenvolvimento e Tandler et alii, 1970 os identificaram nos ductos estriados das glândulas labiais humanas.

As células basais observadas têm características de células mioepiteliais já descritas em glândulas salivares de mamíferos (Young \& Van Lennep, 1977). Na glândula intermaxilar de anfíbios, Müller (1932) descreveu a presença de núcleos basais nos túbulos secretores, sugerindo pertencerem às células musculares lisas. Provavelmente, a principal função da célula mioepitelial dos ductos excretores da glândula intermaxilar é de favorecer a eliminação da secreção impedindo seu refluxo. Young \& Van Lennep (1977) sugerem que a contração destas células, levaria a saliva rapidamente até à boca do animal, para captura de presas. No caso dos anfíbios isto estaria de acordo com as observações de Wiedersheim, 1876; De Vos, 1935.

\section{REFERENCIAS}

Alves, M.S.D., 1979. A glândula intermaxilar do sapo (Bufo paracnemis Lutz, 1925): Estu do anatômico, histológico, histoquímico e ultra-estrutural. Tese de mestrado, Departamento de Morfologia do ICB da UFMG.

Andrew, W., 1964. Comparative aspects of structure of the salivary glands. In: Sreebny, L.M. \& J. Meyer. ed. Salivary Glands and their secretions. New York, Pergamon Press, p. 3 .

Cuttler, L.S.\& A.P.Chaudhry. 1975. Cytodifferentiation of striated duct cells and secretory cells of the convoluted granular tubules of the rat submandibular gland. Am. J. Anat., 143:201-218.

De Vos, C.M. , 1935. Spelaeophryne and the bearing of its cranial anatomy on the monophyletic origin of the ethiopian and malagasy Microhylids. Anat. Anz., 80:241265 .

Fahrenholtz, C., 1934. Die glandula intermaxillaris einer Blindwühle (Uraeotyphlus menoni). Gegenbaurs Jb. Bd., 73:461-468.

Fahrenholtz, C., 1937. Drüsen der mundhole. In: Bolk, L.; E. Goppert; E. Kallius \& W. Lubosh. ed. Handburch der wergleichenden Anatomie der wirbeltiere. Urban Berlin Wien, vol. 3, p. 115-210. 
Vol. 5(4), 1988

Fox, H.; R. Mahoney \& E. Bailey. 1970. Aspects of the ultrastructure of the alimentarycanal, and associated glands of the Xenopus laevis larva. Árchs. Biol. (Liége) 81:21-50.

Francis, E.T.B., 1961. The sources and nature of salivary secretions in amphibia. Proc. zool. Soc., Lond., $136: 453-476$.

Junqueira, L.C.U. \& F. Fava de Moraes. 1965. Comparative aspects of the vertebrate major salivary glands biology. In: Botherman, W., ed. Secretion and Excretion. Berlin, Springer Verlag, p. $36-48$.

Junqueira, L.C.U., 1967: Control of cell secretion. In: Schneyer, L.H. \& C.A. Schneyer, ed. Secretory Mechanisms of salivary glands. New York and Londres, Academic Press, p. 286-302.

Leeson, C.R., 1967. Structure of salivary glands. In: Code, Charles F., ed. Alimentary Canal. Washington, D.C., American Physiological Society, p. 463-495.

Lima, T.G., 1976. Estudo radioautográfico da secreção de glico-proteínas na glândula submandibular da camundonga (Mus musculus) após injeção de L. $\left(1^{-3} \mathbf{H}\right)$ - FUCOSE. Tese de mestrado, Departamento de Morfologia do ICB da UFMG.

Müller, E., 1932. Untersuchungen über die mundhölen drusen der anuren Amphibien. Morph.Jb., 70:131-172.

Oeder, R., 1905. Die Intermaxillardrüse der krôte. Zool. Anz., 24:538-539, Engelmann, Leipzig.

Oeder, R., 1906. Die Entstehung der Munddrüsen und Zahnleiste der Anuren. Jenaische Zeitschr. F. Naturwissensch. 41:506-523.

Oppel, A., 1900. Lehrbuch der vergleichenden mikroskopischen anatomie der wirbeltiere, 3:513-521, G. Fischer, Jena.

Ramaswani, L.S., 1936. The morphology of Bufonid Head. Proc. zool. Soc. London, 4: 1157-1169.

Reichel, P., 1883. Beiträge zur morphologie der Mundhölendrüsen der Wilbertiere. Morph. Jahrb., 8:1.

Richman, I.; M. Gelfand \& J.M. Hill. 1947. A method for descalcifying bone for histologic section. Arch. Path., 44:92-95.

Riva, A.; M. Del Fiacco Testa-Riva \& M.S. Lantini. 1976. Fine structure and cytochemistry of the intra-lobular ducts of the human parotid gland. J. Anat., 122:629-640.

Schelegel, 1833. in Ph. Fr. de siebolds Fauna japonica. J. Müller et Co., ed. Amstelodami.

Schackleford, J.M. \& W.H. Wilborn. 1968. Structural and histochemical diversity in mammalian salivary glands. Ala. J. Med. Sci., 51:180-203.

Tandler, B.; C.R. Denning; I.D. Mandel \& A.H. Kutscher. 1970. Ultrastructure of human labial salivary glands. III. Myoepithelium and ducts. J. Morph., 130:227-246.

Tandler, B. \& R.A. Erlandson. 1976. Ultrastructure of Baboon parotid gland. Anat. Rec., $184: 115-132$. 
Revta bras. Zool.

Tucker, R., 1958. Taxonomy of the salivary glands of vertebrates. Systemic Zool., 7:7483.

Wiedersheim, R., 1876. Die kopfdrüsen der geschwänzten Amphibien und die Glandula intermaxillaris der Anuren. Zeitschr. F. Wiss. Zoll. Bd. XXVII:1-50.

Williams, T.W., 1948. The visualization of vertebrate capillary beds by intra-vascular precipitation of lead chromate. Anat. Rec., 100:115-126.

Williams, T.W. \& C.C. Boyer. 1965. A procedure for selective differentiation of ephitelial derivatives in gross blocks of embryonic and adult tissues. J. Dent. Res., 44:763-767.

Young, J.A. \& E.W. Van Lennep. 1977. Morphology and physiology of salivary myoepithelial cells. In: Robert K. Crane. Ed., Gastro Intestinal Physiology II vol. 12, University Park Press-Baltimore, pp. 105-125.

Zylberberg, L., 1976. Donnés histologiques sur les glandes linguales de quelques batraciens anoures. J. Biol. Buccale, 4:237-259.

Zylberberg, L., 1977. Histochemistry and ultrastructure of amphibian lingual glands and phylogenetic relations. Histochem. J., 9:505-520. 